\title{
Rediscovering and Rethinking Leopold's Green Fire
}

\author{
Holmes Rolston, III
}

\begin{abstract}
Aldo Leopold shot a wolf a hundred years ago, the most iconic wolf kill in conservation history, a shooting now historically confirmed, which three decades later he elevated into his "green fire" metaphor and symbol. There are tensions. Was Leopold a hypocrite? He spent the rest of his life hunting and trying to produce more game to kill. Thinking like a mountain, thinking big in the big outdoors, there is a dramatic shift of focus from a dying wolf's eyes to a land ethic. Thinking big enough, globally, Leopold saving wolves, or wilderness, or game management seems simplistic and parochial before global warming or environmental justice. Still, Leopold is on a moral frontier.
\end{abstract}

\section{THE SHOOTING-REDISCOVERED AND CONFIRMED}

"Shoot!! They're wolves, not deer! See her shake that big tail coming out of the river." Rifles emptied, the mother wolf was down. One yearling pup was limping past some willows into bushy rocks. The others had vanished. Recently, I stood on a rimrock bluff high over the Black River, about where Aldo Leopold shot those wolves, over a hundred years ago, on Sunday, 19 September 1909. This was to become the most iconic wolf kill in conservation history. ${ }^{1}$

I saw no wolves. But I did see a mule deer crossing that same river below, and thought, "Maybe I could hit her with a telescopic sight, but not with the iron sights Leopold had."

Leopold's rifle was a Winchester .30-.30 model 1894, a carbine. From where I stood, this might have been a shot of 125 to 150 yards. Two of them, Leopold and a buddy, Mike Wheatley, emptied their guns and hit only two wolves.

My granddaddy also had a Winchester saddle rifle, only his was a .38-.40. That caliber was designed so that the same bullet went in pistol and rifle. I had that gun on my own mantel for half a century. As Leopold said, it's hard to shoot downhill. I couldn't have hit anything with it at this distance.

Leopold scampered from bluff down to river to encounter green fire in the wolf's dying eyes. I looked for a route by which he might have gone down. Not there,

\footnotetext{
* Department of Philosophy, Colorado State University, Fort Collins, CO 80523. Rolston is University Distinguished Professor and Professor of Philosophy at Colorado State University. He has taught environmental ethics for over four decades and has lectured on all seven continents. He is the author of many articles and books starting with Philosophy Gone Wild (Buffalo, N.Y.: Prometheus Books, 1986) and Environmental Ethics: Values in and Duties to the Natural World (Philadelphia: Temple University Press, 1988) and more recently A New Environmental Ethics: The Next Milennium for Life on Earth (New York and London: Routledge, 2012). A version of this paper in streaming media, originally presented at Utah Valley University, may be found at http://hdl.handle.net/10217/80888.

${ }^{1}$ Aldo Leopold, "Thinking like a Mountain," A Sand County Almanac (New York: Oxford University Press, 1969), pp. 129-33.
} 
too steep. Maybe there, and that does come out where there are willows and slide rocks. As Leopold reached the dying wolf, holding his rifle between himself and the wolf, "the wolf gnashed out and grabbed the rifle butt in its teeth" according to a memory that comes though his son Luna, who still had the scarred gun. ${ }^{2}$

My guide to the overlook was Don Hoffman, who was forest ranger in the Apache National Forest for a quarter of century, later Executive Director of the Arizona Wilderness Coalition: He recalled: "I've known this country for most of my life. I first read Leopold when I was a ranger fire fighter on the porch of that cabin you are staying in - the green fire essay so many times I could recite it from memory. I know for sure where he was camped-on what we call the PS ranch site about two miles north. He names the ranch in his letter. I've read the reports Leopold filed and right here is as likely a spot as any on the river."

\section{GREEN FIRE—METAPHOR AND SYMBOL}

Leopold recalls, "We were eating lunch ..." when they saw the wolves. I also ate lunch at the site. I recalled the excitement that Leopold still recalled when, three decades later, he penned his "Thinking like a Mountain," one of the most influential essays in conservation literature from the last century. What happened in minutes in this then remote wilderness in Apache National Forest, Arizona, was a shot heard round the world. His Sand County Almanac, with this as one of its most powerful essays, has sold two million copies and been translated into twelve languages.

Leopold did not write "Thinking like a Mountain," until April 1944, when he was trying to get published and his editor thought he needed something with more punch. ${ }^{3}$ So given this essay, written three and a half decades later, and no evidence of such a real event in his extensive reports, some have wondered if it were poetic license. But no more. In 2009 a letter surfaced, thanks to the research of Susan Flader, University of Missouri, probing into letters in the bank box of a relative. Toward the end of a nine-page letter, to his mother he writes: "Wheatley and I have killed 2 Timber Wolves and 2 Turkeys and a lot of grouse, but no deer." 4 He laments their bad luck with deer, and the loss of his pipe, also that it is getting cold. There is no epiphany here, but this also leaves no doubt that this kill that he later recalls seared into his memory actually took place.

Leopold had graduated from Yale University earlier that year, and moved from Ivy League to boondocks. He was only a couple weeks on the job, twenty-two years old. He was assigned to do some surveying, prospective to some timber cutting. In the date line of his letter, 22 September 1909, Leopold is explicit about his location when he wrote the letter: Camp No. 2, Milligan Cienega Sec. 19 T. 49 R.

\footnotetext{
${ }^{2}$ Curt Meine, Aldo Leopold: His Life and Work (Madison: University of Wisconsin Press, 1988), pp. 93-94.

${ }^{3}$ Ibid., pp. 453-59.

${ }^{4}$ Aldo Leopold, "To Clara Leopold (22 September 1909)," Curt Meine, ed., Aldo Leopold: A Sand County Almanac and Other Writings on Ecology and Conservation (New York: Library of America, 2013), pp. 740-42.
} 
28E." The problem is that the precise information in his dateline cannot be correct in the grid data, and nobody knows a cienega (spring, small marsh) by that name. Leopold may have been operating with some old maps, and he was new to his job. But we do know the general location. In the same letter Leopold locates his camp at "Slaughter's Ranch," setting camp there on 10 September. I went to the PS Ranch, named for Paul Slaughter. This was where Leopold was camped, as we know from his letter. A long-standing building was probably already there when Leopold was there. Leopold seems not to have stayed in the ranch house, but to have camped nearby. That building burned in the 2011 fire, and the burned ruins were evident.

The wolf kill was on 18 September, his day off, when he was turkey hunting. Most of the adjacent landscape is flat or semi-rolling. There is river and rimrock cutting through the landscape, so you have to track that cut. The rim rock situation he describes best fits the place where I was standing, maybe two miles from his camp. Or if not here, somewhere close by.

I spent a day exploring the rim for other possible sites. Rimrock to rimrock, river below, talus slide slopes and willows on this side of the river, range that made a lucky shot possible, a feasible route down often steep canyon walls by which Leopold could have hurried down to the river, an overlook spot that they might have chosen for lunch with a view, decent turkey habitat on the rimrock above.

\section{GAME MANAGEMENT - PREDATORS AND PREY}

Leopold spent the rest of his life hunting and, as game manager, trying to produce more game to kill. I spooked a deer at the Leopold kill site, close enough to see her eyes as she looked up just before she ran off. Leopold seems never to have seen fire in any deer's eye. He shot ducks and late in life recalls, without remorse, his youthful "delight" as one fell and landed belly up "red legs kicking." wolf that Leopold shot here cared for her pups but cared only to put out fire in the eyes of any deer. Both she and Leopold could only see in a deer meat to eat. Yes, Leopold could write movingly of the green fire in the dying mother's eyes. But one might wonder if he was a hypocrite in real life-putting out fire in the eyes of his "game" for decades afterward.

A few years later he was still (officially, on the job, at least) advocating exterminating not only the wolves, which were already few, but also the lions, still plentiful enough to kill thousands of deer. Wolves had become the scapegoat for the hated predators. The green fire had not yet burned deep enough. Leopold led a campaign to eradicate wolves and lions. He told sportsmen and stockmen: "It is going to take patience and money to catch the last wolf or lion in New Mexico. But the last one must be caught before the job can be fully successful." 6

\footnotetext{
${ }^{5}$ Leopold, "Red Legs Kicking," Sand County Almanac, pp. 120-22.

${ }^{6}$ Aldo Leopold, "The Game Situation in the Southwest." Bulletin of the American Game Protective Association 9, no. 2 (April 1920): 3-5 (https://play.google.com/books/reader?id=IJLkAAAAMAAJ\& printsec $=$ frontcover $\&$ output $=$ reader $\&$ authuser $=0 \& \mathrm{hl}=$ en $\& p g=$ GBS.PA27).
} 
Leopold moved away from eliminating the hated predators to seeing their role in the ecosystem. "I thought that because fewer wolves meant more deer, that no wolves would mean hunter's paradise. But after seeing the green fire die, I sensed that neither the wolf nor the mountain agreed with such a view."7 But as far as he has yet gotten, this is only revising his account of game management. He realizes that wolves regulate the deer population, and can contribute to good hunting.

Since then I have lived to see state after state extirpate its wolves. I have watched the face of many a newly wolfless mountain, and see the south-facing slopes wrinkle with a maze of deer trails. I have seen every edible bush and seedling browsed, first to anaemic desuetude, and then to death. I have seen every edible tree defoliated to the height of a saddlehorn. Such a mountain looks as if someone had given God a new pruning shears, and forbidden Him all other exercise. In the end the starved bones of the hoped-for deer herd, dead of its own too-much, bleach with the bones of the dead sage, or molder under the high-lined junipers. ${ }^{8}$

But this only leaves wolves on the mountain for better hunting. There is not yet any serious looking into those eyes with respect for life. Leopold has only reached a functional account of predators and prey. It took some time for the green fire to burn deeper. The next challenge is to respect the integrities of both predators and prey, entwined in the ecosystem dynamics. Leopold saw green fire in the eyes of a dying mother wolf. Most of the wild creatures that saw those green eyes were prey about to be eaten. Wolves put out the fire in the eyes of deer. All of us need time to accept a world built on predation. We come to empathize, to sympathize with both hunter and hunted. Animals hunt and howl, find shelter, seek out their habitats and mates, feed their young, flee from threats, grow hungry, thirsty, hot, tired, excited, sleepy. They suffer injury and lick their wounds. Life is at stake, requiring defense. There is success, and failure. There is death, but, with labor and regeneration, life ongoing. Each seeming advance - from plants to animals, from instinct to learning, from sentience to self-awareness, from nature to culture - steps up the pain. Earthen natural history might almost be called the evolution of suffering. But that makes it equally plausible to call it the evolution of caring. Proactive caring appears in the world, marvelously incarnate in the wolf, one of the most successful predators in natural history.

The flora and lower faunal forms participate in this struggle, though only in later, higher forms, does the capacity for suffering evolve. Now there must also be endurance - in the more sentient creatures, passionate endurance. Over evolutionary time the fight for life deepens into sentience, and sentience into suffering. Life is indisputably prolific; it is just as indisputably pathetic, almost as if its logic were pathos. The fertility is close-coupled with the struggle. Something is always dying, and something is always living on.

\footnotetext{
${ }^{7}$ Leopold, Sand County Almanac, p. 130.

${ }^{8}$ Ibid., pp. 130-32.
} 
Earth slays her children, a seeming evil, but bears an annual crop in their stead. This prolife, generative impulse is the most startling and valuable miracle of all. The "birthing" is nature's orderly self-assembling of new creatures amidst this perpetual perishing. In a hurtless, painless world, there could never have come to pass anything like these dramas in botanical and zoological nature that have happened, events that in their central thrusts we greatly treasure. There are sorts of creation that cannot occur without death, without one life seeded into another, and these include the highest created goods. Death can be meaningfully integrated into the biological processes as a necessary counterpart to the advancing of life. Hunters typically think that predation justifies hunting. "Green fire in dying eyes" is the metaphor. Fitting predators and prey into one's world view was germinating in Leopold's mind, and I revisited that tragic view of life as I revisited that spot.

Being in wolf country, like being in bear country, changes the feel of the woods. Although I hardly expected it, I realized on that rim that I might still see a wolf. I was in the recovery zone for the Mexican wolf. Wolves rarely attack humans; still "wolf at the door" is a powerful image. I have hiked grizzly country, sometimes alone, and that does keep you on the alert. Leopold notes that a few tracks "made even the most hard-bitten cowboys aware of bear." "Fear of being prey, though seldom experienced now, is as ancient as any form of human consciousness. Realizing that you might be prey is also part of what it means to think like a mountain. At the Leopold kill site, I had no fears of being eaten, but then again I had to realize that all the animals in those woods did live in constant fear of being eaten. Hunters are on the alert; their prey equally so. I was safe enough from any physical threat, but I had found myself alerted by intellectual threat - what to make of predators and prey, of eating and being eaten.

\section{THINKING LIKE A MOUNTAIN - WOLVES AND ECOSYSTEMS}

Leopold also has an essay in Sand County Almanac on Escudilla, a commanding mountain on the same landscape. ${ }^{10}$ I found myself, walking in Leopold's steps, a century later, accepting predators and prey, but still trying to think like a mountain. The landscape that surrounded Leopold had what he called "a hair-trigger equilibrium," a delicate balance of predators and herbivores, easily triggered into degradation by removing keystone species. ${ }^{11}$ What moved him on this spot, though, was green fire in the eyes of the wolf he had just shot. Maybe we need them both - the self-transforming encounter with a particular wild other that triggers thinking big about the big outdoors.

Only mountains, Leopold said, know how to listen to the howl of a wolf. That

\footnotetext{
${ }^{9}$ Ibid., p. 134.

${ }^{10}$ Ibid., pp. 133-37.

${ }^{11}$ Susan L. Flader, Thinking like a Mountain: Aldo Leopold and the Evolution of an Ecological Attitude toward Deer, Wolves, and Forests (Columbia, Mo.: University of Missouri Press, 1974), p. 43.
} 
is literary device - with the punch that Leopold's editor wanted — and it does get us thinking. If the "green fire" metaphor forces rethinking predators and prey, the "thinking like a mountain" metaphor forces thinking about keystone predators in ecosystems. There is no "green fire" in a mountain. Literally speaking, mountains, like Leopold's "land," know nothing. There isn't even any genetic information in them. But if we think ecosystemically of a community of life, that webwork of individuals inhabiting their niches is packed with know-how.

The top predator in that Black-Blue River range was the wolf. Leopold moves in the same sentence from wolf to mountain, from mountain to wolf, but I found myself worrying that he too easily shifts levels by several orders of magnitudefrom inert rocks to a highly sentient mammal. Such evolution took three to four billion years. There is a dramatic shift of focus. Energy flow in a trophic pyramid is fact of the matter (when wolves eat deer who have eaten grass); but the blunt fact of the matter here was: dying mother wolf. Her crippled pups now hidden up there in the brush would soon starve.

Evolutionary natural history may generate caring. But mountains don't care. Entering a trailhead one often sees warnings: "Take care. Mountains don't care." Over tricky steep terrain, I try to think what might be the last of every step, lest I fall and find myself crippled, hungry, and cold. I have been in such situations where I wondered if I could get out. Then you do enter existentially into the struggle for life in the midst of its perpetual perishing. Mountains don't care, but I do care-about myself. That connects me with others in the woods who also care about themselves - and forces the question of my cares for their cares.

I hunted when I was younger, and shot a squirrel once, in Southern Appalachian woods. It fell to the ground, but managed to scramble into a hole in a big oak a few feet up the trunk. I couldn't get it out, and listened to it groan in pain for half an hour. I came back later that afternoon and it was still in there groaning. I found myself wondering. I was just hunting for fun, although I would have eaten the squirrel. Did I really have to cause such suffering, for my entertainment? Obstinate memories make the ephemeral encounter enduring.

Jerry Eckert, economist at Colorado State University, spent several years as visiting professor at Stellenbosch University in South Africa. On a kudu hunt, he chanced to get a shot at a large cheetah, wounded it, and reached it to have it bolt by him so close the cheetah's tail brushed him. Then the desperate animal jumped twice again and collapsed. "I saw a crumpled pile of blood-smeared spotted hide, one long leg jutting skyward and two eyes still open, seeing nothing." Eckert recalls an empty silence, regretting his kill. "That scene still smolders, branded in my memory, an image of feline tranquility and sublime wild power." "My cheetah ranks as the thirty-second largest ever recorded in 110 years of Rowland Ward records." But he hung up the rifle with which he had hunted for forty years; that was "his last shot."12

\footnotetext{
12 Jerry Eckert, "Last Shot," Pilgrimage (Pueblo, Colorado) 35, no. 2 (2010): 86.
} 
Leopold hunted another forty years. Yet he was uneasy, and came later to regret "my sin against the wolves."13 "I was young then, and full of trigger-itch." 14 Many a hunter, growing older, has less trigger itch. Leopold and maybe even the wolf enjoyed their killing, though, in my experience, all thoughtful hunters kill with a pang of sorrow. Maybe dying green fire in eyes sees in hunter and hunted something of the tragedy of life. Killing and eating is the law of life for carnivores. On the wild prairie, Leopold concludes, "The only certain truth is that its creatures must suck hard, live fast, and die often." 15

\section{LAND ETHIC - RESPECT FOR LIFE, LANDSCAPE INTEGRITY}

"Thinking like a mountain" does lead Leopold to a land ethic. That is, after all, "the upshot" in A Sand County Almanac. "The land ethic simply enlarges the boundaries of the community to include soils, waters, plants, and animals, or collectively: the land." "A thing is right when it tends to preserve the integrity, stability, and beauty of the biotic community. It is wrong when it tends otherwise." "That land is a community is the basic concept of ecology, but that land is to be loved and respected is an extension of ethics."16

The land ethic is about loving nature. Maybe my thoughts were lingering too long on predators and prey, the struggles of the survival of the fittest, on the tragedy in life. A Sand County Almanac celebrates integrity, beauty, stability all across the land. The predators belong because they contribute to land health. Leopold's green fire experience triggers in him a new perspective on predators and prey; that grows in him over his lifetime, and the upshot is his likewise converting landscape managers, natural resource professionals, and environmentalists across the country. When Leopold looks over the landscape he sheds no tears; rather with him we learn to rejoice in purple mountain majesties towering over fruited plains. Maybe we shed tears if, in youthful ignorance, we kill a mother wolf; maybe we lament the loss of wildlife on the landscape, but we rejoice when wolves are back in place as keystone predators on at least some of our landscapes.

Thanks to what happened here-Leopold's repentance when he saw the fire in the dying wolf's eyes - I myself have seen far more wolves than Leopold ever did. The restoration of wolves to Yellowstone, now some fifteen years ago, was one result of Leopold's starting here to think like a mountain. Leopold was one of the earliest advocates of restoring wolves to Yellowstone. ${ }^{17}$ So I have seen perhaps a

\footnotetext{
13 Cited in Flader, Thinking like a Mountain, p. 102.

${ }^{14}$ Leopold, Sand County Almanac, p. 130.

15 Ibid., p. 107.

16 Ibid., pp. 204, 224-25, viii-ix.

${ }^{17}$ Curt Meine, "Early Wolf Research and Conservation in the Great Lakes Region," in Adrian P. Wydeven, Timothy R. Van Deelen, and Edward J. Heske, eds., Recovery of Gray Wolves in the Great Lakes Region of the United States: An Endangered Species Success Story (New York: Springer, 2009), p. 10.
} 
hundred wolves alive and alert, mostly in Yellowstone, some in Minnesota. Leopold never records seeing another wolf alive. He recalls this event in 1919, presumably, with a little confusion, when, in the context of a turkey hunt in the Datil National Forest, he is griping about steel bullets. ${ }^{18}$ Late in life, he planned to consult with the National Park Service at Isle Royale about reintroducing wolves there, but he was unable to follow through on account of his health - and the wolves crossed from the mainland soon thereafter. ${ }^{19}$

Thanks to what happened here we do have a Wilderness Society, of which Leopold was a leading founder. That society has been a principal advocate of setting aside wilderness. When the original Wilderness Act was passed in 1964, fifty-four areas (9.1 million acres) in thirteen states were designated. Since then, Congress has enacted additions a hundred times and the wilderness system has grown almost every year and now includes 758 areas $(109,494,508$ acres) in forty-four states and Puerto Rico. Overall, about five percent of the entire United States is protected - an area about the size of California. But because Alaska contains just over half of America's wilderness, only about 2.7 percent of the contiguous United States is protected-about the area of Minnesota. Still, this remarkable wilderness system results from transformed ways of thinking about landscapes, respect for life, and ecosystem integrity, launched by Leopold, and launched in him by green fire in a dying wolf's eyes.

Thanks to what happened here we have better learned what we most need to know about nature: how to value it. As a result, on the Colorado State University campus, I have spent a career insisting that an education these days requires becoming environmentally literate, just as much as it does becoming computer literate.

\section{BEYOND GREEN FIRE? THINKING LIKE THE EARTH}

Leopold was turkey hunting on his day off, a Sunday. Revisiting the site, I was on vacation. Yes, I was in a philosophical mood, thinking big in the big outdoors. Yes, I found that Leopold had left his impact on what Americans think about the big outdoors. But when I thought big enough, globally, I got another switch. Leopold's "green fire" seemed quite irrelevant. He just wanted game to hunt, maybe a land ethics for the countryside around his shack, maybe to save some wilderness. But we need today to save the Earth. Saving wolves in Arizona or Yellowstone, or setting aside the Bob Marshall Wilderness does nothing whatsoever to solve any of the main problems on the world agenda of environmental ethics today, over a century later. Environmental ethics today is a whole new game; the goal posts are off Leopold's scale.

Leopold was onto something bigger than he knew, as prophets often are. Still,

\footnotetext{
${ }^{18}$ Aldo Leopold, "A Turkey Hunt in the Datil National Forest” (1919), in David E. Brown and Neil B. Carmony, Aldo Leopold's Southwest (Albuquerque: University of New Mexico Press, 1995), pp. 44-51.

${ }^{19}$ Meine, "Early Wolf Research," p. 10; Meine, Leopold: Life and Work, p. 497.
} 
he never faced any of the issues now paramount in environmental ethics. Leopold forged his ethic in the sand counties of Wisconsin, though he was quite aware that persons around the globe need a land ethic. He also wrote of New Mexico, of Iowa, lamented the lack of wilderness in Germany and hoped it could be saved in the Carpathian Mountains of central Europe, or in Siberia. But Leopold did not face the global issues now critical in developing environmental ethics; he wrote little about the future of Earth as a planet.

Leopold knew nothing of the hole in the ozone layer, of global warming. He did not face issues of sustainable development in Africa or the Amazon nor questions of environmental justice, where the poor bear disproportionally the burdens of environmental degradation. Ecofeminism did not exist in his lifetime; so he never faced its strident claims that the domination of women is inextricably linked with the domination of nature. He does not deal with escalating populations in the Third World, nor with the consumer culture produced by global capitalism. He does not mention the World Bank, or the North American Free Trade Agreement (NAFTA), or the World Trade Organization (WTO), with their environmental policies, or lack thereof. Nor does he ask who owns genetic resources in tropical rain forests, who can patent their use, nor whether ivory should be sold or banned in order best to protect elephants. He does not worry about the rights of indigenous peoples, or about the release of genetically engineered organisms into natural environments. Leopold's land ethic can seem simplistic, almost parochial before the urgency and complexity of these global issues.

But when I think about it again, I wonder. Maybe Leopold is still a prophet. Ethics in the modern West, has been almost entirely interhuman ethics, persons finding a way to relate morally to other persons - loving our neighbors. Ethics seeks to find a satisfactory fit for humans in their communities, and this has meant that ethics has often dwelt on justice, fairness, love, rights, or peace, settling the disputes of right and wrong that arise among us. But ethics now is anxious also about the troubled planet, its fauna, flora, species, and ecosystems. In the global picture, the late-coming, moral species, Homo sapiens, arising a few hundred thousand years ago, has, still more lately in this century, gained startling powers for the rebuilding and modification, including the degradation, of this home planet.

Environmental ethics, started by a forester spending his weekends in a shack in the rural sand countries, will be taken by some, even yet, to be peripheral concern about chipmunks and daisies, extrapolated to rocks and dirt. But not so. The four most critical issues that humans currently face are peace, population, development, and environment. All are entwined. Human desires for maximum development drive population increases, escalate exploitation of the environment, and fuel the forces of war. Those who are not at peace with one another find it difficult to be at peace with nature, and vice versa. Those who exploit persons will typically exploit nature as readily - animals, plants, species, ecosystems, and Earth itself.

One can, if one wishes, say that concern for the environment is only enlightened human self-interest. One can, if one wishes, say that concern for justice and equitable 
distribution of resources is only enlightened self-interest. We do all benefit from sustainable development in a sustainable biosphere, as we do from justice and fair resource distribution. Still, a perspective with more depth sees entwined destinies, people with other people, people with their planet, responsible caring in human and biotic communities. Environmental ethics is the elevation to ultimacy of an urgent world vision.

We are searching for an ethics adequate to respect life on this Earth, the only planet yet known with an ecology. On Earth, home to several million species, humans are the only species who can reflect about their land ethic, about the future of the planet. Earth is the planet "right (suitable) for life," and ethics asks about the (moral) "right to life" on such a planet. Certainly it seems "right" that life should continue here, a matter of "biotic right," as Leopold put it. ${ }^{20}$ Life is, in the deepest sense, the most valuable phenomenon of all. Life must be sacrificed for the support of life, on which principle ecosystems are founded. Life might be sacrificed to support more abundant life. Still, these long-continuing life processes are the miracle of Earth, and have become, as never before, our evolutionary and ecological responsibility.

Nature has equipped Homo sapiens, the wise species, with a conscience to direct the fearful power of the brain and hand. Perhaps conscience is less wisely used than it ought to be when, as in classical Enlightenment ethics, it exempts the global community of life from consideration, with the resulting paradox that the self-consciously moral species acts only in its collective self-interest toward all the rest. Among the remarkable developments on Earth with which we have to reckon, there is the longstanding creative genesis of myriads of species. There is the recent, explosive human development; and there ought to be, and is, a developing environmental ethic that optimizes natural values in complement to human concerns.

We are not so enlightened as we supposed, not until we reach this Earth ethics. This is the biology of ultimate concern. This is seeing further than Leopold, but we see so far because we stand on this giant's shoulders. We are traveling deeper into ethics than ever before, unfolding a worldview that Leopold began to envision, an urgent call for respect for life globally. The land ethic has become Earth ethics.

I have found, and found again last summer, walking in Leopold's steps, that reflection about who I am, where I am, and what I ought to do needs to happen in wildness as much as in town.

Then on a still night, when the campfire is low and the Pleiades have climbed over rimrocks, sit quietly and listen for a wolf to howl, and think hard of everything you have seen and tried to understand. Then you may hear it . . . a vast pulsing harmony ... its score inscribed on a thousand hills, its notes the lives and deaths of plants and animals, its rhythms spanning the seconds and the centuries."

\footnotetext{
${ }^{20}$ Leopold, Sand County Almanac, pp. 211, 204.
} 
Leopold found in this experience "a sense of kinship with fellow-creatures; a wish to live and let live; a sense of wonder over the magnitude and duration of the biotic enterprise." 21

"Live and let live" is not an option for wolves - hardly for humans either, who equally must eat. But then again maybe humans can figure out more of an ethic where humans live, and let live, the biotic communities surrounding them. In these days of celebrating the Anthropocene, where many conservation biologists are contending that we must put people first and focus on saving primarily the nature that serves our needs, where we conserve what is good for us, dubious of whether nature is good in itself, Leopold remains a prophet. Leopold's experience here, he later said, reflecting on its impact across his life, "constitutes one of the milestones in moral evolution." 22 Leopold found himself on a moral frontier when he found himself on the Western frontier. I found myself, revisiting his site, reconsidering our moral frontiers for the coming millennium. "Thinking like a mountain" triggered "thinking like the Earth."

${ }^{21}$ Ibid., pp. 149, 109.

${ }^{22}$ Aldo Leopold, Game Management (New York: Charles Scribner's Sons, 1948), p. 19. 